\title{
TRADISI UPACARA KEMATIAN PADA ETNIS KARO DI DESA SUKANDEBI KECAMATAN NAMANTERAN KABUPATEN KARO
}

\author{
Indah Permata Sari Bukit ${ }^{1}$ \\ Hafnita Sari Dewi lubis ${ }^{2}$ \\ Fakultas Ilmu Sosial Universitas Negeri Medan \\ Permatasarii762@gmail.com
}

\begin{abstract}
ABSTRAK
Penelitian ini bertujuan untuk mengetahui bagaimana pelaksanaan Tradisi Upacara Kematian Pada Masyarakat Karo di Desa Sukandebi Kecamatan Namanteran Kabupaten Karo. Jenis penelitian ini adalah penelitian Deskriptif Kualitatif dengan menggunakan metode penelitian digital, dimana penulis melihat dan mengamati melalui kaset $\mathrm{CD}$, kemudian penelitian lapangan untuk melakukan wawancara dengan narasumber dan didukung dengan penelitian Library research. Hasil penelitian yang diperoleh menunjukkan bahwa dalam melaksanakan tradisi upacara kematian, hal pertama yang akan dilakukan oleh masyarakat Karo adalah Runggu (musyawarah) oleh kalimbubu, sukut dan anak beru. Kemudian acara yang dilaksanakan selanjutnya adalah pembayaran utang adat, Utang adat pada kematian cawir metua dinamakan "maneh-maneh" dan barang yang diberikan kepada kalimbubu berupa beka buluh dan kain jongkit. Pada jenis kematian tabah-tabah galuh, utang adat nya dinamakan "morah-morah" dan barang yang diberikan kepada kalimbubu berupa baju jas atau kebaya ataupun pakaian sehari-hari selama hidupnya. Dan pada upacara kematian mati muda dinamakan sebagai "sapu-sapu iluh" barang yang diberikan kepada kalimbubu adalah baju yang dipakai semasa hidupnya. Kemudian acara gendang (menari) sekaligus pemberian kata penghiburan kepada keluarga yang ditinggalkan. Dalam pelaksanaan pembayaran utang adat akan dilaksanakan sesuai dengan kesepakatan dan kesanggupan perekonomian dari keluarga yang mengalami kematian tersebut. Barang serta benda yang dijadikan sebagai utang adat juga dapat disesuaikan dengan kesanggupan keluarga, oleh karena itu biasanya utang adat harus dibayar meskipun barang yang diberikan hanya berupa baju sehari-hari yang dipakai oleh orang yang meninggal tersebut. Jika utang adat orang yang meninggal tersebut tidak dibayar, maka dikemudian hari juga harus dibayar kan oleh anak-anaknya. Karena utang adat merupakan suatu kewajiban bagi masyarakat Karo untuk dijalankan.
\end{abstract}

Kata Kunci : Upacara Kematian, Utang Adat. Maneh-Maneh, Morah-Morah, Sapu-Sapu Iluh. 


\section{PENDAHULUAN}

Salah satu suku yang ada di Indonesia adalah suku bangsa Karo. Kata Karo berasal dari kata "Haro" yang artinya pendatang. Penelusuran dari sejarah Kerajaan haru sebenarnya migrasi atau pergerakan orang Karo dari pantai/pesisir menuju pedalaman/pegunungan sudah membentuk lingkaran atau arus bolak-balik. Setelah penaklukan Kerajaan Haru II Deli tua, orang Karo "lari” ke pedalaman dataran tinggi Karo Seberaya.

Tinggi rendahnya budaya suatu bangsa tercermin dari materi-materi budaya yang ada pada bangsa itu. Suku karo sebagai bagian dari bangsa Indonesia yang besar, pada masa lampau telah memiliki budaya leluhur. Kebudayaan suku Karo terdiri dari sisstem kekerabatan, bahasa, marga, adat-istiadat dan pakaian adatnya yang didominasi oleh warna merah dan hitam.

Karakteristik atau identitas dari sifat orang Karo memiliki cirri khas yang berbeda dengan etnis lain yang terdapat di Sumatera Utara. Karakteristik orang Karo cenderung dipengaruhi oleh lingkungan alam yang mengitarinya, terutama dalam memenuhi kebutuhan hidup. Sebagai masyarakat yang tinggal di dataran tinggi tanah Karo dan sekitar hilirnya ternyata sebagai sebuah komunitas, disana juga terbentuk sebuah budaya yang menjadi patron bagi masyarakat Karo dalam berhubungan dengan sang pencipta, alam beserta isinya dan khususnya hubugan antara masyarakat didalamya. Semua pola hubungan tersebut tertuang dalam sebuah aturan tidak tertulis yang mengatur yang disebut dengan tradisi.

Tradisi merupakan hasil dari pemikiran manusia setelah melakukan interaksi dengan sekitanya. Tradisi ini menunjukkan suatu identitas yang melekat pada orang Karo. Interaksi ini di lakukan oleh kelompok masyarakat yang nantinya menjadi sebuah subsistem kebudayaan yang telah menjadi suatu tradisi dalam kelompok masyarakat. Oleh karena itu, kebudayaan dapat diartikan sebagai suatu kelakuan maupun hasil kelakuan dari kelompok masyarakat yangdidapat dengan cara belajar dan tersusun dalam setiap kehidupan manusia maupun kelompok masyarakat. 
Salah satu bentuk subsistem budaya yang masih dijalankan sampai saat ini adalah upacara tradisional yang berkaitan dengan subsistem budaya Religi. Dimana hal ini merupakan sesuatu yang memiliki tujuan, yaitu memberikan penghormatan kepada leluhur, pengucapan syukur, dan permohonan syukur maupun keselamatan kepada sang pencipta maupun sang leluhur. Fungsi dari upacara tradisional bagi kelompok masyarakat adalah sebagai pengelola norma maupun nilai-nilai kebudayaan yang berlaku dalam kehidupan kelompok masyarakat tertentu.

Berbagai macam upacara tradisional yang masih dijalankan sampai saat ini, dan salah satunya adalah Tradisi Upacara Kematian yang dilaksanakan dalam masyarakat suku Karo. Ada suatu kepercayaan pada masyarakat Karo bahwa bila seseorang meninggal dunia, sebenarnya unsur-unsur jasmaniah dan rohaniahnya kembali ke asalnya semula. Demikianlah pentingnya upacara kematian ini bagi masyarakat, sehingga baik sebelum dan sesudah diadakan penguburan terdapat beberapa upacara yang biasa dilakukan sesuai dengan jenis kematian yang dialami masyarakat Karo didaerah Tertentu.

Berdasarkan uraian diatas, yang telah dijelaskan mengenai kebudayaan masyarakat karo dalam subsistem budaya religi yaitu melaksanakan upacara tradisi kematian pada masyarakat Karo. Peneliti merasa tertarik untuk meneliti lebih lanjut dan mendapatkan pemahaman lebih dalam, oleh karena itu penulis akan melakukan penelitian dengan judul "Tradisi Upacara Kematian Pada Etnis Karo Di Desa Sukandebi Kecamatan Namanteran Kabupaten Karo”

Berdasarkan uraian masalah diatas, identifikasi masalah dan batasan masalah penelitian diatas maka rumusan penelitian ini adalah bagaimana tata cara pelaksanaan upacara kematian pada masyarakat Karo di desa sukandebi.

\section{METODE DAN FOKUS PENELITIAN}

Jenis penelitian ini adalah penelitian Deskriptif Kualitatif dan metode yang digunakan pada penelitian ini yaitu metode penelitian lapangan (Field research), dimana peneliti langsung meninjau kelapangan untuk mendapatkan data informasi dari 
narasumber. Data yang didapat dengan menggunakan metode penelitian Digital, Field research, dan didukung dengan menggunakan metode penelitian Library research. Library research adalah penelitian dengan menggunakan literatur-literatur yang berhubungan dengan masalah yang akan diteliti.

\section{HASIL DAN PEMBAHASAN}

Berdasarkan data yang diperoleh dari lapangan bahwa masyarakat Karo yang juga memeiliki sistem kekerabatan sendiri. Kerabat (kade-kade) dalam Masyarakat Karo terbentuk oleh karena hubungan keturunan atau karena perkawinan, sehingga terjadilah hubungan kekerabatan baik antara pihak wanita dan pihak pria yang menikah.

Hubungan kekerabatan karena keturunan melahirkan kategori "sembuyak"atau "senina". Hubungan kekerabatan karena aperkawinan menimbulkan kategori-kategori "kalimbubu"(kerabat atau klen atau subklen asal istri) dan anak beru (kerabat atau klen atau subklen dari pihak suami anggota kerabat yang perempuan).

Dalam tesis (Usaha Ginting, hl.70) dikatakan bahwa tiap-tiap masyarakat, walaupun dalam bentuk yang sederhana sekali, akan dapat menemui suatu bentuk kehidupan keluarga, pengakuan mengenai ikatan kekeluargaan, sistem ekonomi dan politik, status sosial, ibadah agama, cara menyelesaikan konflik dan hukuman terhadap penjahat dan lain-lain disamping kebudayaan material, suatu kumpulan pengetahuan mengenai alam semesta, teknik dan tradisi. Demikian hal nya dengan masyarakat Karo memiliki sistem kekerabatan yang diwariskan secara turun temurun yang mencakup bentuk ikatan kekeluargaan, sistem sosial dan politik, penyelesaian konflik, dan berbagai hal yang terkait dengan sistem kekerabatan.

Setiap individu pada masyarakat Karo baik yang bermukim di kawasan kabupaten Karo maupun diluar kabupaten Karo kendati telah membaur dengan etnik lain sekitarnya pada umumnya mengetahui sistem kekerabatan yang berlaku menjadi pedoman dari sistem kekerabatan. Berikut tatanan kehidupan masyarakat Karo yang terikat dalam suatu sistem kekerabatan. 


\section{Upacara Kematian}

Upacara kematian merupakan salah satu upacara besar yang masih melekat pada masyarakat karo. Ada suatu kepercayaan pada masyarakat Karo bahwa apabila seseorang meninggal dunia. Sesungguhnya unsur-unsur jasmaniah dan rohaniahnya kembali ke asalnya semula. Dalam kepercayaan masyarakat karo orang yang dikatakan mate (meninggal) adalah orang yang sudah tidak bernafas, daging dan badan sudah tidak dapat merasakan, tidak lagi merasakan lelah, susah selesai tugasnya di dunia ini, ada dua pemahaman yang berhubungan dengan roh manusia, dimana dalam masyarakat karo percaya bahwa roh nya yang hidup akan kembali kepada Dibata (Tuhan) dan roh nya yang mati akan menjadi begu (Hantu).

Demikian pentingnya kematian ini bagi masyarakat, sehingga baik sebelum dan sesudah diadakan penguburan atau pembakaran mayat terdapat beberapa upacara yang biasanya dilangsungkan tergantung pada jenis kematian nya.

Berikut jenis kematian pada masyarakat Karo dan cara pelaksanaan upacara kematian pada masing-masing jenis kematian di masyarakat Karo:

\section{Pelaksanaan Tradisi Upacara kematian Cawir Metua}

Dikatakan meninggal dalam keadaan "cawir metua" baik laki-laki maupun perenpuan bila, semua anak nya sudah berkeluarga dan sudah memiliki cucu serta usia sudah lanjut (tua). Pelaksanaan upacara cawir metua ini dapat dikategorikan menjadi 2 jenis, yaitu:

a. Cawir Metua kalimbubu Rose (Berpakaian Adat Karo)

Semua anak-anak saudara sepupu harus rose, artinya harus menggunakan pakaian Adat Karo. Acara gendang atau menari pada upacara cawir metua kalombubu rose juga lebih banyak yang harus dilakukan, yaitu: gendang sukut, gendang acara rose(berpakaian adat), gendang setelah selesai berpakaian adat, gendang kalimbubu dan gendang anak beru.

b. Cawir Metua kalimbubu La Rose ( Tidak menggunakan pakaian Adat Karo) 
Anak-anak, cucu-cucu almarhum tidak perlu menggunakan pakaian Adat Karo dan pelaksanaan nya lebih simpel. Acara gendang yang harus dijalankan yaitu: gendang sukut, gendang kalimbubu dan gendang anak beru.

Menurut pernyataan (Saleh Sitepu) Pengaruh ekonomi dan waktu biasanya akan menyebabkan masyarakat Karo banyak lebih memilih pelaksanaan upacara kalimbubu la Rose, hal ini dikarenakan biaya yang dibutuhkan lebih sedikit dan pelaksanaan nya lebih simpel. Biasanya penentuan pelaksanaan upacara kematian cawir metua rose maupun tidak rose akan dibahas pada tahap Runggu yang dihadiri oleh kalimbubu, senina dan anak beru.

Karena berdasarkan penelitian yang penulis lakukan di desa sukandebi, upacara kematian cawir metua yang dilaksanakan adalah upacara cawir metua Kalimbubu La Rose, maa yang akan saya bahas dalam pelaksanaan upacara cawir metua berikut ini adalah jenis upacara kematian cawir metua kalimbubu la rose.

Acara pertama yang akan langsung dilaksanakan ketika ada keluarga atau kerabat yang meninggal duni adalah Runggu (musyawarah) dengan sangkep geluh (sukut, kalimbubu, anak beru). Pada awal acara runggu, hal yang harus dilakukan terlebuh dahulu adalah erkimbang (menggelarkan tikar putih). Runggu ini biasanya akan dilaksanakan pada malam hari. Hal-hal yang akan dibicarakan ddalam runggu ini yaitu mengenai proses pelaksanaan adat dan penguburan yang akan dilakukan. Berikut hal-hal yang akan dibicarakan:

1. Tempat penguburan, peti yang akan digunakan, dan juga waktu penguburan.

2. Tata cara penguburan, besar kecilnya acara yang akan dilaksanakan, dan jenis makana yang akan disajikan.

3. Kelengkapan adat yang harus dilaksanakan seperti gendang adat dan pakaian adat.

4. Menentukan pihak keluarga yang akan menerima kain adat pada saat pembayaran utang adat.

5. Tata tertib pelaksanaan upacara adat sampai pada penguburan. 
Selanjutnya acara yang akan dijalankan adalah nggalari utang adat (membayar utang adat) (maneh-maneh) kepada kalimbubu. Dalam upacara kematian Sukut mempunyai kewajiban membayar utang adat kepada pihak kalimbubu dan puang kalimbubu. Utang adat tersebut terdiri atas barang dan sejumlah uang (biasanya orang Karo menyebut uang tersebut dengan batuna). Barang yang diberikan biasanya adalah uis(kain) adat dan juga pakaian milik almarhum, uang yang diberikan tidak ditentukan jumlah nya tergantung kesepakatan dari pihak keluarga.

Jumlah barang dan uang yang diberikan kepada kalimbubu tidak ada perbedaan baik yang meninggal laki-laki ataupun perempuan. Hanya saja apabila yang meninggal laki-laki yang menerima utang adat ada tiga pihak sementara apabila yang meninggal perempuan yang menerima utang adat ada empat pihak.

Berikut pihak yang menerima utang adat apabila yang meninggal laki-laki, yaitu :

1. Kalimbubu singalo ulu emas

2. Kalimbubu singalo ciken-ciken

3. Anak Beru

Semua kalimbubu diberikan kain adat yaitu "beka buluh", sedangkan anak beru diberikan sekin (parang) beserta benang telu rupa (benang tiga warna) biasanya benang ini berwarna merah, putih, hitam yang diikatkan pada parang tersebut.

Parang tersebut diberikan dengan makna bahwa parang yang digunakan anak berunya tersebut selama melaksanakan tugas "pejabu" ( mengawinkan) anak dari kalimbubunya yang meninggal sudah menikah semua, sehingga perlu diberikan gantinya. Namun sekarang ini benang telu rupa tersebut sudah tidak pernah diikutkan lagi sehingga yang diberikan kepada anak beru hanya senin beserta batuna saja.

Pihak yang menerima utang adat apabila yang meninggal perempuan adalah :

1. Kalimbubu simupus

2. Kalimbubu singalo bere-bere

3. Kalimbubu singalo perkempun

4. Anak Beru 
Semua kalimbubu menerima kain adat yaitu kain "jongkit”, sedangkan anak beru diberikan parang dan kampil (tempat sirih) beserta benang telu rupa yang berwarna merah putih dan hitam yang diikatkan pada kampil (tempat sirih) tersebut.

Setelah selesai membayar semua utang adat kepada kalimbubu, maka acara yang akan dilaksanakan selanjutnya adalah acara gendang atau menari. Acara ini dilakukan agar sukut, kalimbubu, tetangga, kepala desa beserta jajarannya dan anak beru dapat memberikan unek-unek dan kata penghiburan kepada keluarga yang ditinggalkan. Dalam acara inipun haruslah berjalan sesuai dengan urutan sangkep nggeluh pada peradatan orang karo yaitu:

1. Sukut

2. Seluruh pihak kalimbubu

3. Kepala desa, tetangga, perkumpulan Gereja/Masjid

4. Anak beru

Setelah selesai memberikan kata penghiburan dan menyampaikan segala sesuatu yang ingin disampakan kepada keluarga yang ditinggalkan, maka selanjutnya kalimbubu akan memberikan uis dagangen (kain Kafan) kedalam peti anak berunya yang meninggal.

\section{Pelaksanaan Tradisi Upacara Kematian Tabah-Tabah Galoh}

Tabah-tabah Galoh merupakan sebutan dalam masyarakat Karo untuk orang yang meninggal dalam keadaan sudah menikah dan memiliki anak, namun anakanaknya belum menikah semua atau dikatakan juga orang yang meninggal tersebut masih ada tanggung jawab yang belum dipenuhi yaitu menikahkan anaknya.

Dalam pelaksanaan nya pun tidak jauh berbeda dalam setiap jenis kematian dimana hal pertama yang harus dilakukan oleh keluarga yang ditinggalkan adalah melakukan Runggu ( musyawarah). Sama halnya dengan sbelumnya hal-hal yang akan dibahas dalam runggu ini adalah:

1. Tempat penguburan, peti yang akan digunakan, dan juga waktu penguburan.

2. Tata cara penguburan, besar kecilnya acara yang akan dilaksanakan, dan jenis makana yang akan disajikan. 
3. Kelengkapan adat yang harus dilaksanakan seperti gendang adat dan pakaian adat.

4. Menentukan pihak keluarga yang akan menerima kain adat pada saat pembayaran utang adat.

5. Tata tertib pelaksanaan upacara adat sampai pada penguburan.

Setelah mencapai kesepakatan diantara semua puhak, maka selanjutnya acara yang harus dijalankan ialah pembayaran utang adat dimana di setiap jenis kematian pada masyarakat Karo, utang adat memang harus selalu dibayarkan kepada kalimbubu. Utang adat yang harus dibayarkan kepada kalimbubu pada kematian jenis Tabah-tabah galoh diberi nama Morah-Morah. Jumlah dan jenis barang yang bibayarkan sama kepada setiap kalimbubu baik peremmpuan maupun laki-laki dan batuna (uang) yang diberikan tergantung pada kesepakatan antara kalimbubu dan anak beru.

Apabila laki-laki yang meninggal dunia, maka pihak yang menerima utang adat tersebut adalah:

1. Kalimbubu singalo ulu emas

2. Kalimbubu singalo ciken-ciken

3. Anak Beru

Barang yang diberikan kepada kalimbubu adalah baju jas atau pakaian yang dipakai semasa hidupnya beserta batuna (uang) yang telah disepakati jumlahnya.

Apabila perempuan yang meninggal dunia, maka pihak yang menerima utang adat adalah:

1. Kalimbubu Sngalo Beru

2. Kalimbubu Singalo Bere-Bere

3. Kalimbubu Singalo Perkempun

4. Anak Beru

Utang adat yang harus diberika kalimbubu adalah baju kebaya atau pakaian yang dipakai semasa hidupya beserta batuna (uang) sesuai denganyang telah disepakati. 
Dan kepada anak beru biasanya akan diberikan barang berupa Rempu Sekin (pengikat sarung parang) beserta benang telu rupa. Alasan diberikannya rempu ini adalah anak beru belum selesai mengerjakan tugasnya untuk menikahkan anak dari kalimbubunya yang meninggal sehingga parang nya belum cukup tumpul untuk diganti dengan parang baru sehingga yang diberikan hanya sarungnya saja.

\section{Pelaksanaan Tradisi Upacara Kematian Mate Nguda/Muda}

Dikatakan mate nguda/muda jika orang tersebut meninggal dalam keadaan belum menikah. Walaupun belum menikah utang adat yang dibayarkan harus ada karena selama ia hidup walaupun belum menikah ia telah memiliki peran dalam kegiatan-kegiatan pesta adat yang dilaksanakan oleh sangkep nggeluhnya.

Sama halnya dengan sebelumya, hal pertama yang dilaksanakan adalah runggu (musyawarah). Hal-hal yang akan dibahas dalam runggu ini adalah:

1. Tempat penguburan, peti yang akan digunakan, dan juga waktu penguburan.

2. Tata cara penguburan, besar kecilnya acara yang akan dilaksanakan, dan jenis makana yang akan disajikan.

3. Kelengkapan adat yang harus dilaksanakan seperti gendang adat dan pakaian adat.

4. Menentukan pihak keluarga yang akan menerima kain adat pada saat pembayaran utang adat.

5. Tata tertib pelaksanaan upacara adat sampai pada penguburan.

Berikutnya masuk kedalam acara pembayaran utang adat, utang yang harus diberikan kepada kalimbubu pada acara upacara adat kematian muda dinamakan sebagai "Sapu-sapu iluh" (pengelap air mata).

Pihak yang menerima utang adat jika yang meninggal laki-laki :

1. Kalimbubu singalo ulu emas

2. Kalimbubu singalo ciken-ciken

3. Anak beru 
Utang adat yang harus dibayarka kepada kalimbubu hanya baju beserta batuna karena yang meninggal merupakan anak perana dan belum menikah, dan untuk anak beru juga diberikan benang telu rupa dan batuna.

Pihak yang menerima utang adat apabila yang meninggal perempuan:

1. Kalimbubu singalo bere-bere

2. Kalimbubu singalo perkempun

3. Anak beru

Hanya tiga pihak saja yang harus diberikan utang adat, karena pihak kalimbubu singalo beru belum dimiliki oleh anak perempuan yang meninggal belum menikah. Karena kalimbubu singalo beru merupakan kalimbubu dari pihak suaminya.

Kalimbubu juga diberikan baju yang dikenakan semasa hidupnya yang dimaknai sebagai sapu-sapu iluh beserta batuna, anak beru juga diberikan benang telu rupa beserta batuna. Makna benang telu rupa yang diberikan kepada anak beru ini ialah agar anak beru tetap menjaga kekompakan sukut, kalimbubu dan anak beru.

Karena meninggal dalam keadaan belum menikah maka terdapat salah satu acara yang harus dilaksanakan, yaitu:

1. Jika yang meninggal adalah laki-laki, maka akan diambil seruas bambu muda dan dimasukkan kedalam petinya oleh anak beru laki-laki secara sembunyi-sembunyi.

2. Jika yang meninggal adalah perempuan, maka akan diambil dahan pohon aren yang telah dibentuk dan dimasukan kedalam peti nya oleh anak beru yang perempuan secara sembunyi-sembunyi.

Hal ini dilakukan agar yang meninggal tidak lagi mengganggu atau menginginkan impal nya sebagai pasangan hidupnya karena bambu dan pohon aren tersebut dimaksudkan sebagai makna anak beru telah melakukan kewajibanya untuk menikahkan nya. 


\section{Perbedaan Pelaksanaan Upacara Kematian Berdasarkan Agama}

Agama asli pada masyarakat Karo sebelum diperkenalkan oleh para pendakwa Islam dan misionaris Kristen ke Tanah Karo adalah Kiniteken Sipemena (Agama Pemena). Kepercayaan yang paling tua di tanah karo adalah Dinamisme dan animisme (Roh). Dalam kepercayaan ini dilakukan pemujaan atau penyembahan kepada roh-roh yang dianggap suci dan berkuasa; pada tempat-tempat dan waktu-waktu tertentu (E.P. Ginting, 1999).

Setelah semakin berkembang nya zaman, maka pada masa sekarang masyarakat Karo menganut berbagai agama besar di dunia, terutama agama-agama samawi, yaitu Kristen dan Islam. Antara umat beragama ini di dalam masyarakat Karo terjadi toleransi dan saling menghargai perbedaan-perbedaan yang hidup bersama di dalam satu wilayah budaya, yaitu desa Sukandebi kecamatan Namanteran.

Dalam pelaksanaan upacara adat kematian tersebut bagi masyarakat Karo yang memeluk agama kristen akan dilaksanakan sebagaimana mestinya adat dalam upacara kematian pada masyarakat Karo. Sedangkan untuk masyarakat Karo yang memeluk agama islam acara adat kematiannya akan dijalan kan setelah penguburan dilakukan. Karena dalam agama islam tidak boleh dilaksanakan penguburang dalam waktu yang lama.

Menurut penjelasan dari bapak sungkunen sembiring, yang mengatakan bahwa perbedaan dalam menjalankan adat upacara kematian bagi orang-orang karo yang beragama kristen dan islam terletak pada proses penguburan nya. Proses penguburan akan tetap dijalankan sesuai dengan kepercayaan dalam agama masing-masing.

\section{PENUTUP}

Selain menganut asas patrilineal yaitu garis keturunan ayah masyarakat karo juga menarik garis keturunan dari ibu yang disebut sebagai bere-bere. Sangkep nggeluh pada masyarakat Karo merupakan salah satu sistem kekerabatan yang tidak dapat dipisahkan yang disebut dengan rakut sitelu yang terdiri dari kalimbubu, senina/sembuyak dan anak beru. 
Pelaksanaan upacara kematian pada masyarakat karo dapat dikelompokkan menjadi 3 jenis yaitu, cawir metua, tabah-tabah galuh dan mati muda. Secara umum dalam pelaksanaan nya dari ketiga jenis kematian tersebut sama. Namun, hal yang membedakannya adalah utang adat yang harus dibayarkan kepada kalimbubu berbedabeda dari masing-masing jenis kematian tersebut.

Utang adat pada kematian cawir metua dinamakan "maneh-maneh" dan barang yang diberikan kepada kalimbubu berupa beka buluh dan kain jongkit. Pada jenis kematian tabah-tabah galuh, utang adat nya dinamakan "morah-morah" dan barang yang diberikan kepada kalimbubu berupa baju jas atau kebaya ataupun pakaian seharihari selama hidupnya. Dan pada upacara kematian mati muda dinamakan sebagai "sapu-sapu iluh" barang yang diberikan kepada kalimbubu adalah baju yang dipakai semasa hidupnya.

\section{DAFTAR REFERENSI}

Ginting Suka, Sada Kata. 1997. Ranan Adat : Orat Nggeluh-Rikut Kiniteken Kalak Karo Ope Tubuh Seh Idilo Dibata. Yayasan Merga Silima.

Gintings. 1997. Adat Karo I Bas Kalak Mate : Kinata Berita Simeriah Kerna Kematen I Bas Masyarakat Karo. Kabanjahe. Perc. Abdi Karya.

Kartodirdjo, Sartono. 2017. Pendekatan Ilmu Soaial Dalam Metodologi Sejarah. Yogyakarta. Ombak.

Koentjaraningrat. 2005. Pengantar Antropologi Pokok-pokok Etnografi II. Jakarta. PT. rineka Cipta.

Muhamad Ali Pawiro. 2017. Tradisi Nurunken Kalak Mate Cawir Metua Dalam Masyarakat Karo. Universitas Sumatera Utara. Medan. Disertasi.

Pulumun Peterus Ginting. 2015. Spiritualitas Upacara Gendang Kematian Etnik Karo Pada Era Globalisasi. Universitas Udayana. Bali. Disertasi.

Putro, Brahma. 2014. Karo Dari Zaman ke Zaman. Medan. Ulih Saber.

Satyananda, Made I dkk. 2013. Kearifan Lokal Suku Helong Di Pulau Semau Kabupaten Kupang Nusa Tenggara Timur. Yogyakarta. Ombak. Sjamsuddin, Helius. 2016. Metodologi Sejarah. Yogyakarta. Ombak.

Tarigan, Henry Guntur.1990. Percikan Budaya Karo. Medan. Yayasan Merga Silima. Tarigan, sarjani. 2008. Dinamika Orang Karo, Budaya Dan Modernisme. Medan. Yayasan Merga silima.

Tarigan, sarjani. 2010. Dinamika Peradatan Orang Karo. Medan. Balai Adat Budaya Karo Indonesia 